\title{
Womanism, land and the cross: In memory of Vuyani Vellem
}

Author:

Fundiswa A. Kobo ${ }^{1}$ (D)

\section{Affiliation:}

${ }^{1}$ Department of Christian Spirituality, Church History and Missiology, College of Human Sciences, University of South Africa, Pretoria, South Africa

\section{Corresponding author:} Fundiswa Kobo,

kobofa@unisa.ac.za

Dates:

Received: 21 July 2021

Accepted: 15 Oct. 2021

Published: 25 Jan. 2022

How to cite this article: Kobo, F.A., 2022, 'Womanism, land and the cross: In memory of Vuyani Vellem', HTS Teologiese Studies/ Theological Studies 78(3), a6997. https://doi. org/10.4102/hts.v78i3.6997

\section{Copyright:}

(C) 2022. The Authors. Licensee: AOSIS. This work is licensed under the Creative Commons Attribution License.

\section{Read online:}

Scan this QR code with your smart phone or mobile device to read online.
Premised by Vuyani Vellem's deep-seated understanding of spirituality and the cross expressed in 'Whoever wants to be my disciple must deny themselves and take up their cross and follow $\mathrm{me}^{\prime}$, the paper explores the paradox of learning to die in order to live, which is a dominant message of the Gospel. The cross that symbolises humiliation, oppression and death, is also the cross that symbolises liberation, life and resurrection. The liberative power of the cross concealed in the establishment/dungeons of oppression and bigotries of racism and sexism, can be located in the institution of the church that has become an establishment that Christ stood against. The paper thus looks at the cross, that is, spirituality in juxtaposition to racism, patriarchy and the establishment/dungeons, and posits that one cannot begin to embrace the cross unless one is also conscious of the darker side of the cross. Excavating spirituality and the cross from the establishment is a statement of critique of ideological frames that have shaped the liberation story or narrative that is indisputably racist and patriarchal. To follow Christ is to embrace a spirituality epitomised and exemplified in struggles against the bigotry of racism and patriarchy, and it is to embrace a spirituality that enables one to learn to die in order to live.

Contribution: This paper on womanism, land and the cross that attempts to deal with paradoxes, at epistemological, cultural and metaphysical levels, engages the work of the late Prof Vuyani Vellem whose life and scholarship was embedded in paradoxes in the quest for the liberation of black humanity.

Keywords: cross; Vuyani Vellem; spirituality; racism; sexism; establishment; dungeons; land.

\section{Introduction}

Learning to die in order to live is a paradox presented by the cross from black and womanist theological perspectives. It is in reflecting deeply on the meaning of the cross by black people in a racist and sexist society that illusions of the cross are exposed. Learning to die in order to live became a reflection of my own spirituality as I struggled to deal with the demise of the late Prof Vuyani Vellem whose convictions were deeply embedded in this paradox. I reflect later on some of these paradoxes evoked by his demise. In my first tribute, I make a point that there is no civilisation or culture devoid of paradox and assert the intent of this article as an attempt to deal with paradoxes, at epistemological, cultural and metaphysical levels (Kobo 2020). Kobo's (2020) words are apt for what this article is attempting,

[F]or example, Christian Faith offers the Cross of Jesus as a tool that can enable us to deal with paradoxes. The cross itself is a symbol of the paradox. It is both ugly and beautiful. (p. 3)

For Cone (2011), the ugliness of the cross points us to the denigration of the humanity of the other, the marginalisation of the other, the oppressive systems and their concomitant violent antics. The cross symbolises humiliation, shame and death; yet it also symbolises liberation, life and resurrection. One of the important things about the cross is that it is the symbol of defeat, yet the symbol of victory! (Kobo 2020:3-4). This paper thus purposes to look at paradoxes, at epistemological, cultural and metaphysical levels, by engaging the work of the late Prof Vuyani Vellem whose life and scholarship were embedded in paradoxes in the quest for the liberation of black humanity.

Initially, this manuscript was titled 'A womanist spiritual dimension of embracing the cross' inspired and, with the aim of engaging Vellem's paper, entitled 'The spiritual dimension of embracing the cross', which exposes how he understood and dealt with paradoxes. The current title 'Womanism, land and the cross: In memory of Vuyani Vellem' equally serves the purpose as he would not like an attempt to regurgitate his thoughts or words. The paper explores the paradox of learning to die in

Note: Special Collection: VukaniBantuTsohangBatho: Spirituality of Black Liberation, sub-edited by Fundiswa Kobo (University of South Africa) and Rothney Tshaka (University of South Africa). 
order to live, which is a dominant message of the Gospel, and thus spirituality and faith. The cross as the symbol of this faith and spirituality symbolises humiliation, oppression and death, yet it symbolises liberation, life and resurrection. The liberative power of the cross concealed in the establishment/dungeons ${ }^{1}$ of oppression and bigotries of racism and sexism, can be located in the institution of the church that has become an establishment/dungeon that Christ stood against. The paper looks at the cross, that is, spirituality in juxtaposition to racism, patriarchy and the establishment/dungeons, and posits that one cannot begin to embrace the cross unless one is also conscious of the darker side of the cross.

The darker side finds expression in the use of Bible, prayer, church, the cross, that is, spiritual resources to justify and rationalise slavery, the loss of land, subjugation and exploitation of black bodies amongst other things. Excavating spirituality from the establishment/dungeon is a statement of critique of ideological frames that have shaped the liberation story or narrative that is indisputably racist and patriarchal from a womanist perspective. I employ a womanist framework, which is inspired by Ogunyemi (1985), a Nigerian novelist who presents womanism as a comprehensive philosophy for black people. It is on the edifice of this philosophy then that a womanist theology, that methodologically places social analysis that evokes black women and their lived experiences at the heart of doing theology in the quest for the liberation of black humanity as a whole is developed (Kobo 2018a). Paulo Freire is one of the scholars that highlighted the importance of social analysis and the animation that arises from the experiences of the oppressed (Freire 1970). My own womanism is black and African, and is inspired by Black theology of liberation and African culture (Kobo 2020).

From a womanist perspective then, to follow Christ, is to embrace a spirituality epitomised and exemplified in struggles against the bigotry of racism and patriarchy, and it is to embrace a spirituality that enables one to learn to die in order to live. This paper attempts to look at the paradoxes of faith, the cross and spirituality in the quest for the liberation of black humanity.

\section{The cross as a site of blackness in cemeteries}

One sees a paradox in the cross of Jesus, with Easter being the most celebrated by black people as they probably relate to crucifixion in a racists world as suggested by Cone (2011). This presents another conundrum when one observes the number of people who flock in for Good Friday services, and

1.The use of establishment/dungeons is intentional and a critique of western, white Theology, Christianity and church which became a dungeon for black people. As observed by Boesak (1977:29) in the following manner: 'When under Constantine Christianity became a state religion, however, the Church changed. From then on Church and State would be allies. The confession of the Church became the Church and State would be allies. The confession of the Church became the confessions of the State, and the politics of the State became politics of the Church The politics of the Kingdom of God would henceforth be subjected to the approva of Caesar. G.J. Heering spoke of "the Fall of the Christian Church" (55) and rightly so. In simple terms, we might say, the Church became a white Church, and subsequent history would prove it.... Once the Christian Church had discovered what could be done with its new-found economic and political power, there was no stopping it in joining fully in all the benefits'. yet on Resurrection Sunday the pews are empty. Mofokeng (1989) offers us a rationale for this as follows:

The reason is not far to find. It derives from the intensity of Good Friday celebrations in Black churches. On this occasion black Christians who pack churches give witness to their understanding of the events around the capture, torture, humiliation and crucifixion of Jesus of Nazareth and how these events relate to them. They experience a transposition to the time of Jesus and consequently suffer with him in Jerusalem. (p. 47)

What Mofokeng is narrating is a story of black people even today in our townships, villages and informal settlements in South Africa, the cross bearers. The pathologies he cited that black Christians give witness and relate to are triple for black Christian women who fill up the pews in almost all black churches where ironically leadership remains male dominated. They are the crucified amongst cross bearers ${ }^{2}$ (Mofokeng 1987) as they embody the stripes that Jesus also embodied, not only from a racist society but also a patriarchal society and as victims of gender-based violence.

One also recalls words uttered by one of the panellists in a Vukani Bantu Tsohang Batho ${ }^{3}$ seminar that celebrated the life of the late Prof James Cone in Cape town in 2018, Nkosi Gola, an activist and a member of this movement who equated life for those residing in townships as hell and further observed that townships are cemeteries, as infrastructures that were designed for non-persons continue to be death traps (Gola 2018). Perhaps Gola is right to use the image of a cemetery if we evoke how Nigel Gibson (2011:165) equates life in the squalor as that 'of struggle against daily living death'. A point affirmed by Vellem in his paper that looks at Thabo Mbeki Village (TMV), an informal settlement in Johannesburg. Vellem narrates the situation of the black people in townships, by observing that 'Death lives at TMV, death is alive at this village and many of us could not survive a week in these conditions' (Vellem 2014:209). Kobo (2018a) makes similar observations in her research that looks at Stoffel Park informal settlement in Pretoria, and talks about death and dying bodies of women in Stoffel Park.

The insights made by Anton Haber who described Diepsloot are helpful in grasping the realities pointed to by Gola above. Haber (2011) postulates:

You have come face to face with the hard reality of Southern African poverty: a dense forest of shacks, crowds of unemployed people milling on the streets...The place has a dull metal glow of aging zinc housing, the chaos of unpaved roads, the noise of a

2. The crucified among the crossbearers: Towards a black Christology' is the title of Takatso Mofokeng's (1987) phenomenal work whose insights resonates with the theme and argument made, but is also used to make the point that black women are triple oppressed from a womanist perspective.

3.Vukani Bantu Tsohang Batho, a movement that was Prof Vuyani Vellem's brainchild, whose aim is to invest in spiritual capital for the spiritual liberation of Black African people in particular and humanity in general. One of the things worth mentioning is how he envisioned a movment that was not confined in the ivory towers of the how he envision a academia; but a movement that was inspired by Paulo Freire theory that highlight the importance of the animation arising from the oppressed, the interloutors of BTL. The rearch team of this movement hosted in 2018 a seminar on 'Spirituality. Black Theology of Liberation' in eKassie, in memory of Prof James Cone within the bounds of Western Cape at the Church of Nezarenes, in Khayelitsha. 
life lived in packed public areas, the smoke of smouldering braziers and the stench of sewage spilling into the streets. (p. 227)

This is the deadly infrastructure earlier equated to a cemetery, which for Vellem is worse for women and children whose bodies lie in these cemeteries of rape and child molestation, crimes that go unpunished as lack of service delivery and inadequate police intervention are a norm (2014:209). 'Clearly if you are poor, black and female you get it in three ways', argued Spivak (1988:537) in her exposition of a triple oppression of poor, black women. Indeed, black women's bodies are sacrificial lambs at the altars of racism, sexism, classism, amongst other constructs of oppression. Vellem (2017) further asserted that black people in South African townships struggle to breathe. For him, 'The hard conditions of squalor and sordid life are an imprint of the past South Africa, the time of colonization and domination' (Vellem 2014:207). Therefore, if we follow this thesis of township as a cemetery, a place of death, the death of Jesus is something that they could easily identify with. Words of reflection on the triumphal entry of Jesus by Chu (2014) are helpful for us. He posits that Hosanna means save us now! God saves us from our oppressors. Which is arguably a link between oppressed black people and the cross on Good Friday as they begin to chant Hosanna with the triumphal entry of Jesus into Jerusalem. In Vellem's (2014:211) research in TMV, some residents, if not most, who reside there believe that God will save them from squalor and that 'God is the source of their lives in living death'. For that reason, Good Friday for them means hope for liberation from the squalor contrary to an understanding of Good Friday as espoused in the authoritative doctrine of salvation. A salvationist religion that cannot be delinked from violence, upheaval and revolt according to Vellem (2014). This is the point the paper is trying to make in its thesis of the darker side of the cross that cannot be escaped in the quest for our liberation as black people.

Briefly, we return to the earlier observation on how black people in our townships flock into churches on Good Friday and yet on Resurrection Sunday, one finds empty pews.

\section{Mofokeng's (1989) observation below is helpful for us:}

There is another side to their experience. Jesus is being abused, tortured, humiliated and crucified in them in their country and in their time. They suffer a long Good Friday throughout their lives, a long Good Friday that relates very closely to Jesus' Good Friday. Jesus' cry of abandonment is their own daily cry. (p. 47)

Mofokeng thus helps to establish the links between the cross and human suffering, and why black people love Easter as they relate with the unjust suffering of Jesus, his crucifixion that affirms theirs in a racist and patriarchal society. Hence Good Fridays are packed.

But then the question still remains that, Easter does not end on Good Friday, but we find empty pews on Resurrection Sunday. Observations of activists' experience of the 1970s by
Magaziner (2010) do shed some light on this conundrum. He observes a morass of doubt mixed with the confidence that a change would come, in time, which one can argue that the lived experiences of many poor South Africans are perhaps a reflection of this paradox pointed to by Magaziner. Vellem (2014:213) posits that, '...they do believe in the resurrected Christ as theirs is a black faith that embraces a gospel of Jesus Christ that proclaims total liberation of the oppressed'. To paraphrase (Mofokeng 1989):

[T] hese Christians reflect on the suffering of Jesus in the light of their own in order to draw consequences which will orientate their own personal lives and communal action towards resurrection in their lifetime. (p. 47)

They are not liberated post 1994, their lived experiences immersed in struggles against the bigotry of racism, sexism, xenophobia, homophobia, which are ...'an antithesis of the promise of life after death in the liberating gospel of Jesus Christ' (Vellem 2014:213). Black and womanist theologies as faith discourses are immersed in the struggles located in these cemeteries: 'solidarity with the most oppressed and materially poor provides a state in which we learn how to live, by actually knowing how to die' (Vellem 2014:212).

Blackness is spiritual, as demonstrated in this section, that exposes the paradox of the cross immersed in cemeteries. Blackness is also a condition of landlessness to which we now turn to in the next section.

\section{Cross and land dispossession}

When the white man [missionaries] first came to our country [Africa], he had the Bible and we had the land. He said, 'let us pray to God'. We closed our eyes and joined him in prayer. When we opened our eyes at the end of the prayer, we saw that we now had the Bible and he had the land (Maluleke 2007:513). ${ }^{4}$

The quote above is a well-known saying attributed to the likes of Desmond Tutu in South Africa amongst other prominent pro-black African leaders, and sets the basis for our discussion of the paradox of the cross and land dispossession for Africans - a history of land dispossession that cannot be separated from cultural killing and erosion of traditional practices and religion of Africans by the colonisers (Kobo 2018a).

Tinyiko Maluleke's (2007) insights and analysis of this wellknown saying are crucial for us:

[S]peaks to the scandal and paradoxical hurdle that faces any would be postcolonial evangelist and/or missionary. The paradox is at once epistemological and practical. The hurdle is tall and firm - one that cannot be brushed aside. No amount of mission historical revision will displace the overwhelming evidence that Christian mission was variously complicit in imperialism, conquest and colonization. It was Christian theology and Christian texts that formed both the backdrop and the ideological framework for the colonial project. To speak of

4.See also, Vellem (2018a:1), "It is said that the missionaries in South Africa said, "let us pray, and after prayer our land was gone, and we only had the Bible in our hands!"”. 
the complicity of Christian mission in the colonial project is therefore not merely to speak of missionaries- what they did or did not do - a mistake made often. Missionaries were after all only one driver of Christian mission in Africa. But there is no need to treat the role of missionaries with analytical kid's gloves either. (pp. 512-513)

Maluleke (2007) makes a pivotal point that:

\begin{abstract}
Missionaries are never an innocent factor in mission. But when we speak of the complicity of Christian mission we are not merely talking of a historical phase or epoch once here and now gone. We are speaking of a continuing reality deeply rooted in the practices of the churches of the colony and the post colony. The scandal is that the Bible and the Christian faith were employed in the facilitation of conquest - 'he had the land, we had the Bible'. (p. 513)
\end{abstract}

Maluleke's analysis needs no further explanation, as he exposes the paradox. The point being: 'In the name of Jesus they stole our land, and they made us strangers in the land of our birth' (Boesak 1987:97). Maluleke makes the point that the darker side of the cross cannot be escaped in the quest for our liberation as black people. He made it clear that the swapping of the Bible with land was mediated through violence and conquest, yet Africans still hold on to the Bible (Maluleke 2007:514). Moore (ed. 1973) affirmed the point made by Maluleke of a continuing reality, and argued that:

$[W]$ hile the white colonists were busy with the process of robbing the people of their land and their independence, the Churches were busy however unconsciously, undermining the will of the people to resist. (p. viii)

Fanon (1961) observes the links between land and dignity of colonised people. Thus, being landless is to be without dignity, perhaps it is to be like an empty shell (Biko 1987). A point well articulated by Ngugi wa Thiong'o (2009:57), who posits 'A person who has lost his land feels the pangs of hunger'. Kobo (2018a) argues that:

[I]n possession of land, black man is exempted from failure to provide for his family, black women from exploitation in white people's homes and black children from a dysfunctional upbringing. (p. 63)

Another point is that for Africans land is spiritual. Land connects us to the living and the dead as umbilical cords are buried in the kraal as a part of rituals that connect us with our ancestors. The loss of land that is the rupture of the umbilical cords, the demonising of ancestors and African religion, is truly a spiritual cry, a cry for life that inspires a womanist in the quest for the liberation of black humanity (Kobo 2016).

The next section reflects on Vellem's paper that exposes this paradox of the cross, land and spirituality.

\section{The spiritual dimension of embracing the cross}

Prayer is one of the most important resources for Christian spirituality. It is said that the missionaries in South Africa said, 'let us pray, and after prayer our land was gone, and we only had the Bible in our hands!' With the land still in their hands, now it is prayer itself that is squeezed out of our souls and our crushed consciences. Today in our world, the skies are throttled, mountains are crumbling, streams and the deeps that bowed in prayerful glory to God are left roaring and their waves lifted on high in piercing groans. Creation is groaning! To pray and to pursue justice is heavy and deep (Vellem 2018a:1).

Prayer in South Africa was used to rob people of their land as demonstrated in the previous section by Maluleke, Boesak, and others. It is a spiritual matter that Vellem also reflected on as he also suggests that the prayer, the Bible and the Cross are being snatched away too by the oppressor. The point is that, one observes contradictions in faith, spirituality, theology and church pointing to a dissonance between theology and ideology as long argued by Black Theology (Boesak [1977]; Maluleke [2007]; Vellem [2014], and other proponents of Black Theology in South Africa). So what one sees now from Vellem's thesis is a clear demonstration of the ideological captivity of the faith, prayer, the Bible and cross by both oppressors and the oppressed. The oppressors are unable to connect the Bible, Cross and Prayer with oppression, yet they have used those spiritual resources to exploit, denigrate, kill and oppress. The oppressed are also eluded by the same analogy because for them, the cross-means liberation. Vellem's (2018a) insights below need no explanation to capture this paradox:

'That the analogy between the cross and the lynching tree should have eluded the Christian agents of white supremacy is not surprising', Cone argues. How could we be surprised when Vasco da Gama and his crew chanted Te Deum Laudamus ${ }^{5}$ after invading the palace of Kilwa here in Tanzania? Liturgy and prayer have served to elude us from the violence of the cross. Many indeed continue to be eluded by the analogy between the cross and the black woman's body in the dungeons of the Elmina Castle. The analogy between the civilizing mission and the cross eludes us in our throttled systems of higher learning, we fail to connect the cross with the deification of a form of democracy completely detached from the daily bread needed by millions of people on the margins, yet only one per cent of the total population enjoys ninety-nine per cent of our global wealth. (p. 2)

For Vellem, the oppressors fail to feel what black people feel at their hands, and thus their inability to feel is an expression of a heart that does not feel. 'It is the heart to feel the burden of the cross that distinguishes elusion from the spiritual embrace of the cross Jesus', argues Vellem (2018a:3). The dungeoning of black women's bodies and black humanity in the Elmina Castle that Vellem, also Kobo (2018b) and Nadar (2005) allude to is a dungeoning that is not felt, yet is at the helm of faith. Looking at Elmina, the assumption is that when

5. Te Deum Laudamus was a prayer-song a doxology of victory of the violent dispossession of land as in the capture of kilwa after Vasco da Gama's ship touched the coast of Natal. Unfortunately, no longer holding by its anchor, getting swung and fatefully drifted by the strong currents of the Indian Ocean, Vasco da Gama's ship ultimately found anchor in Tanzania leading to the violent capture of Kilwa and the singing of Te Deum Laudamus. This should be mindboggling to a victim of land dispossession in South Africa (Vellem 2018b:76-77). 
Psalms were sung upstairs in the chapel located above the female dungeons, the women in the dungeons could clearly hear them. And that the violation of women in the dungeons could clearly be heard by those in the chapel. But the absence of the heart to feel is what we see from this.

Dietrich Bonhoeffer (2015), in the Cost of Discipleship, speaks about the costly price of denying oneself to carry the cross and follow Jesus. Surely for black people, this is a costly exercise, to be able to transcend racism, sexism and other constructs of oppression and carry the cross, that is, a spiritual embrace of the cross. As challenging as it may be, costly grace, suggests Bonhoeffer, is the gospel that must be sought again and again and again, the gift that must be asked for, the door at which a man must knock. Such grace is costly because it calls us to follow, and it is grace because it calls us to follow Jesus Christ. Following a Christ who was a threat to the establishment/dungeon! How do we fight against the establishment, when we have become the establishment/dungeon...is the question of the 21st century that Maluleke (2007:513) points to 'a continuing reality deeply rooted in the practices of the churches of the colony and the post colony'.

Mofokeng (1989) also evokes 'Whoever wants to be my disciple must deny themselves and take up their cross and follow me', which is foundational in Vellem's understanding of the cross. In his analysis of the cross, he speaks about God who emptied Him/Herself of all glory became the lowest of human beings, the Oppressed. And, evokes indignation in us as well as called us to an act of commitment to combat against root causes of human suffering (Mofokeng 1989:46-47).

To deny oneself and follow Christ surely means to follow a Christ who turns tables upside down. Tables of racism, xenophobia, homophobia, patriarchy, abuse of power, exploitation of the poor, corruption...it is to confront death without fear as a response to conflict that is needed and facing up consequences as suggested by Francis and ap Siôn (2016)! One comes to such a conclusion inspired by an approach that according to Francis and ap Siôn (2016:7), 'focusing on the present-day readers of the Gospel narratives and on the theoretical understanding of biblical hermeneutics shaped by psychological type theory'.

\section{Boff (1993) argues that:}

[T] he cross is the death of all systems, it will not fit into a framework,. It bursts all bonds. It is the symbol of total negation... and yet absurd as the cross is, it is still more absurd for God to have taken it up. (pp. 115-116)

Because then 'the cross is the absolute opposite of human value systems' (Cone 2011:35). So ultimately Vellem (2018a) asserts that embracing the cross demonstrates conqueror's capacity to accept defeat in order to feel the pain of the poor. And for the oppressed, it is to subvert tyrannical forms of power.
In the next section, I offer my contribution and observation of what embracing the cross might entail from a womanist perspective.

\section{A womanist spiritual dimension of embracing the cross}

In the 21st century, it is no longer about the struggle itself; it is about the possibility of sinking further whilst struggling to follow Jesus from a womanist perspective. The people who are dancing and struggling against the invading, disintegrating and conquering spirit have been joined by those who keep them dancing and struggling. They are killed by the pharaohs who are part of the singing and worship. The imagery of Pharaohs on both sides of the blood-red waters by Boesak expresses this invasion vividly. The thesis of the invasion, which is demonstrated in this section, is captured by Vellem in his notions of hardening husk (2016), growing fascism of the West (2017) and new blood rivers (2019b). It inspires the researcher to be imaginative as it evokes many conversations with the late Prof Vuyani Vellem specially to assist in thinking of the implications of the invasion on the dungeons.

Following Vellem's thesis, one sees that the issue is no longer the distinction between the spirits that come from outside to destroy; the problem is that in the song of the struggle, in the dungeon today, pharaohs are present. You are dancing as a means to release your body, your existence, from the clutches of Empire, but the problem is that those very people are dancing with you to keep you dancing. You are worshipping with those who are worshipping against your worship. You have now been integrated in a toxic, parasitic manner with those who in fact keep you there so that you will die dancing.

This is a dangerous form of integration. Once the integration solidifies and becomes rigid, the ability to differentiate is completely destroyed. That is what is happening today with integrated forms of spirituality, because they have been joined and solidified by those who are not part of the struggle but are in fact perpetuating the degradation of black humanity and life. If at one time there was a distinction between a song sung by a woman in the dungeons, and another by a woman in the chapel above at Elmina Castle, ${ }^{6}$ the two have now become one.

From my own womanist perspective, the critique is not against disintegration, but against the solidification that arises out of integration, which is the strategy that Empire uses today.

This I have expressed in these words:

They sing my song with me,

they cry with me, they carry the cross with me,

they come in the dungeons with me,

6.For a deeper reflection on Elmina castle as an epitome of dungeoning of black women and humanity, see works by Kobo in 2018. 
yet they want to keep me there

they pray with me, they follow Jesus with me,

they reject racism with me

they reject economic exclusion with me

but they have solidified...to keep me there!

I am seeing an unhealthy, rigid integration that has created sameness in difference or in what must be different. This makes it formidable for me to know whether the song that one hears from the dungeons is indeed a song sung by a woman who is black and naked or by those who are part of that song and who have not been made to be naked but are perhaps choosing to be naked in order to keep those women naked. The nakedness of Elmina women is expressed succinctly by Nadar (2005).

Today many scholars reject patriarchy, racism, economic exclusion and so on, and in so doing, they have chosen to join the dungeons; if lived experiences of black women are our starting point from a womanist perspective, but the song that comes out of the dungeons is confounded and confusing. It is not enough for them to have created the dungeons - they have now penetrated the dungeons to understand the language of the oppressed, to keep them there. After all, for them escape is very easy: they can be airlifted out, whilst for the black woman, the exit is via the Door of No Return.

The issue is about what is left: the pain-filled voice that rises from the dungeons is joined by the voices of those who have sneaked into the dungeons, the tourists in the dungeons, who are singing the song in order for it no longer to be heard. For me, as a womanist, that is the site of the struggle, a continuing reality. To follow Christ, therefore, is to indeed as Vellem observed, embrace a spirituality epitomised and exemplified in struggles against the bigotry of racism and patriarchy, and it is to embrace a spirituality that enables one to learn to die in order to live.

\section{A tribute}

2019 presented a paradox for me, my PhD graduation was the happiest day and the demise of my PhD supervisor the worst. It was a difficult year, yet a joyous year. In the writing of this paper, I cannot escape that reality and that of death itself. The cross teaches us that life comes after death, and that there are prospects of life from stumps, dead and dry bones. An exposition of possible impossibilities presented by the cross and the pertinent question that always arises on whether God is present in death? To which many who have lost their loved ones would respond no, and many whose life in the squalors represents death, the answer would be no.

I bemoan that I can no longer visit his office to ask many questions that fill my mind as I struggle every day to deal with paradoxes. I grieve the one who helped me to attain a level of harmony, tranquillity and affirmation in reconciling the paradox of faith and reason in the quest for liberation of black humanity. His (Vellem 2019b) insistence and dedication to challenge systems and cannons of knowledge that continued to elevate some people over others... which was the cry of life of black people and an exposition of:

$[T]$ he marks of the transatlantic slave trade, the festering wounds of the colonised on the underside of modernity, memory mediated through the colonisation of the mind, apartheid south Africa, a climax of the killing civilisation based on the colouring of bodies. (n.p.)

Umoya (the Spirit) of life is on the rise propelling us to continue to dare to struggle to live in the context of empire not with the dictates and a life killing civilisation of empire. Kubi, Kubi, siyaya, Noba Kubi Siyaya, Noba Besibulala Siyaya (No matter how bad, we are going, no matter if they are killing, we are going). We follow Jesus who was crucified and killed for justice: 'whoever wants to be my disciple must deny themselves and take up their cross and follow me' (Vellem 2018a:4).

I wish to conclude with Prof Vellem's words as one of the respondents to the keynote address in one of his last conferences hosted by Council for World Mission before his demise, '... Socrates once said that a life that is unexamined is life that is not worthy to be lived. The indigenous witness in South Africa, Latin America... and the North America, the communities of indigenous people will continue to inspire us to examine the meaning of life and witness to the alternative existence of life imagined in the 21st century' (Vellem 2019a).

\section{Acknowledgements Competing interests}

The author declares that she has no financial or personal relationships that may have inappropriately influenced her in writing this article.

\section{Author's contributions}

F.A.K. is the sole author of this article.

\section{Ethical considerations}

This article followed all ethical standards for research without direct contact with human or animal subjects.

\section{Funding information}

This research received no specific grant from any funding agency in the public, commercial, or not-for-profit sectors.

\section{Data availability}

Data sharing is not applicable to this article as no new data were created or analysed in this study.

\section{Disclaimer}

The views and opinions expressed in this article are those of the author and do not necessarily reflect the official policy or position of any affiliated agency of the author. 


\section{References}

Biko, S., 1987, I write what I like, Heinemann, Oxford.

Bonhoeffer, D., 2015, The cost of discipleship, Golden Lane, SCM Press, London.

Boesak, A., 1977, Farewell to innocence. A social-ethical study of Black Theology and Black power, Ravan, Johannesburg.

Boesak, A., 1987, If this is treason, I am guilty, Wm. B. Eerdmans Publishing Co., Grand Rapids, MI.

Boff, L., 1993, Passion of Christ, passion of the world. The facts, their interpretation, and their meaning yesterday and today, Orbis Books, Maryknoll, New York, NY.

Chu, J., 2014, Does Jesus really love me?: A gay Christian's pilgrimage in search of God in America, Harper Perennial, New York, NY.

Cone, J.H., 2011, The cross and the lynching tree, Orbis Books, Maryknoll, New York, NY.

Fanon, F., 1961, The wretched of the earth, Grove Press, New York, NY.

Francis, L.J. \& Ap Siôn, T., 2016, 'Jesus, psychological type and conflict: A study in biblical hermeneutics applying the reader perspective and SIFT approach to Mark 11:11-21', HTS Teologiese Studies/Theological Studies 72(4), a3573. https://doi. org/10.4102/hts.v72i4.3573

Freire, P., 1970, Pedagogy of the oppressed, The Continuum International Publishing Group Inc, New York, NY.

Gibson, G., 2011, Fanonian practices in South Africa: From Steve Biko to Abahlali baseMjondolo, University of KwaZulu-Natal, Pietermaritzburg.

Gola, N., 2018, The voice of the grassroots: What is spirituality eKasi? Semina proceedings on Spirituality: Black Theology of Liberation in eKassie in memory of proceedings on Spirituality: Black Theology of Liberation in eKassie in memory of Professor James Cone, hosted by Vukar

Haber, A., 2011, Diepsloot, Jonathan Ball Publishers, Cape Town.

Kobo, F.A., 2016, 'Umfazi akangeni ebuhlanti emzini ... A womanist dialogue with Black Theology of Liberation in the 21st century', HTS Teologiese Studies/Theological Studies 72(1), a3268. https://doi.org/10.4102/hts.v72i1.3268

Kobo, F.A., 2018a, 'A womanist dialogue with black theology of liberation in the twenty first century', Unpublished PhD thesis, University of Pretoria, Pretoria.

Kobo, F.A., 2018b, 'Black women's bodies as reformers from the dungeons: The reformation and womanism', HTS Teologiese Studies/Theological Studies 74(3), 5015. https://doi.org/10.4102/hts.v74i3.5015

Kobo, F.A., 2020, 'Ebuhlanti Amandla ngawethu: Womanism and black theology of liberation, in memory of Vuyani Shadrack Vellem', HTS Teologiese Studies/ Theological Studies 76(3), a6211. https://doi.org/10.4102/hts.v76i3.6211
Magaziner, D.R., 2010, The law and the Prophets: Black Consciousness in South Africa, 1968-1977, Ohio University Press, Athens, OH.

Maluleke, T.S., 2007, 'Postcolonial mission: Oxymoron or new paradigm?', SMTSwedish Missilogical Themes 95(4), 503-528.

Mofokeng, T.A., 1987, 'Following the trail of suffering: Black theological perspectives, past and present', Journal of Black Theology in South Africa 1(2), 21-34.

Mofokeng, T.A., 1989, 'The cross in the search for true humanity: Theological challenges facing South Africa', Journal of Black Theology in South Africa 3(2), 38-51.

Moore, B. (ed.), 1973, Black theology. The South African voice, C. Hurts \& Co., London.

Nadar, S., 2005, 'Searching the dungeons beneath our religious discourses: The case of violence against women and the "unholy trinity"', Agenda 19, 16-22.

Ngugi wa Thiong'o, 2009, 'Recovering our memory: South Africa in black imagination', in Steve Biko Foundation (ed.), The Steve Biko Memorial lectures: 2000-2008, pp. 51-72, Pan Macmillan, Johannesburg.

Ogunyemi, C.O., 1985, 'Womanism: The dynamics of the contemporary black female novel in English', Signs 11(1), 63-80.

Spivak, C.G., 1988, 'Can the subaltern speak?', in C. Nelson \& L. Grossberg (eds.) Marxism and the interpretation of culture, pp. 271-313, Macmillan, London.

Vellem, V.S., 2014, 'Life giving assets at a Johannesburg informal settlement: Black Faith and the false Gods of multiculturalism in the twenty-first century', in R. Drew Smith, W. Ackah \& A.G. Reddie (eds). Churches, blackness, and contested multiculturalism. Europe, Africa and North America, Palgrave Macmillan, New York, NY.

Vellem, V.S., 2016, 'A hardening husk of neoliberal antics: Worrying signs of the times', in Oikotree Movement (ed.), Life-enhancing learning together, pp. 60-77, Less Press \& Life in Beauty Press, Samjeong.

Vellem, V.S., 2017, 'Unthinking the West: The spirit of doing black theology of liberation in decolonial times', HTS Teologiese Studies/Theological Studies 73(3), a4737. https://doi.org/10.4102/hts.v73i3.4737

Vellem, V.S., 2018a, 'The spiritual dimension of embracing the cross', Conference on World Mission and Evangelism, Arusha, Tanzania, March 8-13, 2018, Doc No. PLEN 06.4, Singapore

Vellem, V.S., 2018b, 'limanyano singing Siyakudumisa: Ambivalent worship and the reformed tradition in South Africa', St Augustine Papers: A South African Journal of Interdisciplinary Studies 19(1-2), 75-95.

Vellem, V.S., 2019a, Panellist at the Discernment and radical engagement (DARE) global forum, Council on World Mission and Evangelism, Taiwan.

Vellem, V.S., 2019b, 'Cracking the eurocentric code. A battle on the banks of the "new blood rivers"', Missionalia 46(2), 2019, 267-287. https://doi.org/ $10.7832 / 46-2-313$ 